\title{
Antibacterial Effect of Lime (Citrus aurantifolia) Peel Extract in Preventing Biofilm Formation
}

\author{
Jeffrey, Mieke H Satari, Dikdik Kurnia \\ *Doctoral Program Faculty of Medicine Padjadjaran University \\ Jl. Prof. Eyckman No. 38 Bandung 40161 Indonesia \\ **Department of Oral Biology Faculty of Dentistry Padjadjaran University \\ Jl Sekeloa Selatan no 1 Bandung Jawa Barat Indonesia \\ ***Laboratory of Natural Products Chemistry Department of Chemistry \\ Faculty of Science Padjadjaran University Jatinangor \\ Jl Raya Bandung Sumedang KM 21Kab. Sumedang 45363 Jawa Barat Indonesia \\ Email:jeffrey_dent2000@yahoo.com
}

\begin{abstract}
The routine and long term use of chemicals to maintain oral and dental health have the potency to result in the emergence of side effects; therefore another strategy is needed as an alternative such as using antimicrobial agents extracted from plants. The purpose of this study is to review the effectiveness of lime (Citrus aurantifolia) peel extract as an antibacterial in preventing biofilm formation. Biofilm is a component consisting of bacteria in a self-produced polymeric matrix, attached to an inert surface, alive, and can survive because of its ability to capture nutrients and withstand adverse environmental conditions. Lime peel contains flavonoids which are the largest group of polyphenol compounds that can work as antioxidants and antibacterial by denaturing bacterial cell proteins and damaging bacterial cells. Flavonoids can also inhibit glucosyltransferase (GTF) activity of Streptococcus mutans to prevent biofilm formation. Lime peel extract inhibits the formation of the activity of the enzyme Streptococcus mutans. As a conclusion lime peel extract contains compounds with therapeutic potential and has the effect of inhibiting the formation of the activity of the enzyme Streptococcus mutans so that it can be used to inhibit the formation of biofilms.
\end{abstract}

Keywords: antibacterial, biofilm, Citrus aurantifolia 


\title{
Efektivitas Antibakteri Ekstrak Kulit Jeruk Nipis(Citrus aurantifolia) dalam Mencegah Pembentukan Biofilm
}

\author{
Jeffrey*, Mieke H Satari**, Dikdik Kurnia*** \\ *Program Doktoral Fakultas Kedokteran Universitas Padjadjaran \\ J1. Prof. Eyckman No. 38 Bandung 40161 Indonesia \\ **Departemen Biologi Oral Fakultas Kedokteran Gigi Universitas Padjadjaran \\ J1 Sekeloa Selatan no 1 Bandung Jawa Barat Indonesia \\ *** Laboratorium Laboratory of Natural Products Chemistry \\ Department of ChemistrFaculty of Science Padjadjaran University Jatinangor \\ Jl Raya Bandung Sumedang KM 21Kab. Sumedang 45363 Jawa Barat Indonesia \\ Email : jeffrey_dent2000@yahoo.com
}

\begin{abstract}
Abstrak
Pemakaian bahan kimia dalam memelihara kesehatan gigi danmulut secara terus menerus dalam jangka panjang dapat menimbulkan efek samping, oleh karena itu diperlukan strategi untuk mencari antimikroba alternatif dengan memanfaatkan tumbuhan. Tujuan dari telaah ini adalah untuk memberikan gambaran mengenai efektivitas ekstrak kulit jeruk nipis (Citrus aurantifolia)sebagai antibakteri dalam mencegah pembentukan biofilm. Biofilm merupakan komponen yang terdiri dari bakteri dalam matriks polimerik yang diproduksi sendiri, melekat pada permukaan inert, hidup, dan dapat bertahan karena kemampuannya untuk menangkap nutrisi serta tahan terhadap kondisi lingkungan yang kurang baik.Kulit jeruk nipis mengandung senyawa flavonoid yang merupakan golongan terbesar dari senyawa polifenol serta dapat bekerja sebagai antioksidan dan antibakteri dengan mendenaturasi protein sel bakteri dan merusak sel bakteri. Flavonoid juga dapat menghambat aktivitas glukosiltransferase(GTF) dari Streptococcus mutans untuk mencegah pembentukan biofilm. Sebagai simpulan, ekstrak kulit jeruk nipis mengandung senyawa dengan potensi terapeutik dan memiliki efek sebagai zat penghambat pembentukan aktivitas enzim Streptococcus mutans sehingga efektif digunakan sebagai agen penghambat pembentukan biofilm.
\end{abstract}

Kata kunci: antibakteri, biofilm, Citrus aurantifolia 


\section{Pendahuluan}

Karies gigi merupakan penyakit infeksi yang disebabkan oleh metabolisme bakteri yang memproduksi asam dan menyebabkan terjadinya demineralisasi pada permukaan email serta dentin. Karies gigi secara umum merupakan penyakit yang paling sering terjadi dan menyebabkan masalah kesehatan rongga mulut baik pada anak maupun dewasa. Etiologi utama dari karies gigi adalah Streptococcus mutans melalui pembentukan biofilm yang biasanya sangat rentan terhadap antibiotik dan agen antimikroba, seperti klorheksidin. Klorheksidin sebagai standar emas telah terbukti menunjukkan aktivitas antibakteri, antivirus, antijamur, dan dianggap memiliki aktivitas antiplak. Akan tetapi penggunaan agen ini tidak lepas dari efek samping yang ditimbulkan, yaitu dapat menyebabkan perubahan warna pada gigi, restorasi, dan gigi tiruan, sehingga dibutuhkan bahan herbal lain yang tidak menyebabkan efek samping. ${ }^{1-3}$

Kemungkinan munculnya efek samping tersebut menyebabkan diperlukannya strategi untuk mencari antimikroba alternatif dengan memanfaatkan tumbuhan untuk perawatan berbagai penyakit infeksi.World Health Organization(WHO) memperkirakan bahwa sekitar $80 \%$ dari populasi manusia bergantung pada obat-obatan herbal untuk pengobatan berbagai penyakit. Hal itu karena ketersediaan tumbuhan yang banyak, mudah diperoleh, alasan ekonomi, dan efek samping yang lebih rendah. Ketersediaan tanaman obat tidak menjadi masalah terutama di negara-negara berkembang, dan telah banyak jenis buah dan tanaman yang terbukti memiliki efek sebagai antibakteri. Salah satu tanaman yang dapat dimanfaatkan sebagai agen antibakteri adalah kulit jeruk yang telah banyak diteliti dan menunjukkan aktivitas antibakteri yang kuat. ${ }^{4-6}$

Tujuan dari telaah ini adalah untuk menguraikan data terkini tentang aktivitas senyawa antimikroba kulit jeruk nipis (Citrus aurantifolia) terhadap Streptococcus $s p$. dan kemampuannya mencegah terjadinya pembentukan biofilm plak gigi dan karies. Spesies Streptococcus sebagian besar ditemukan di rongga mulut dan nasofaring; bakteri ini merupakan bakteri yang dominan di rongga mulut sebagai mikrobiota normal pada manusia. Pada individu yang sehat, bakteri ini tidak berbahaya, namun dapat menjadi patogen dan menyebabkan infeksi pada kondisi tertentu. ${ }^{5}$

\section{Karies Gigi}

Karies gigi merupakan penyakit infeksi yang ditandai oleh kerusakan lokal jaringan gigi akibat terjadinya demineralisasi email dan dentin akibat asam yang diproduksi oleh mikroorganisme plak sebagai hasil fermentasi karbohidrat. Bakteri penyebab utama karies gigi adalah Streptococcus mutans yang merupakan bakteri gram positif berbentuk kokus dan 
merupakan flora normal pada rongga mulut manusia. Streptococcus mutans menghasilkan enzim GTF yang dapat mengubah sukrosa menjadi polisakarida ekstraseluler yang larut dan tidak larut seperti glukan dan fruktan dari sukrosa yang berhubungan dengan pembentukan plak dan terjadinya karies, serta merupakan faktor virulensi utama Streptococcus mutans. ${ }^{1,2,7}$

Obat-obatan herbal saat ini sedang diminati dan popularitasnya meningkat dari hari ke hari. Di sektor kesehatan, WHO merekomendasikan dan mendorong penggunaan jamu atau obat tradisional karena bahan baku yang diperlukan tersedia dalam jumlah besar dan mudah didapat. Obat-obatan herbal ini banyak ditemukan di alam dan memiliki aktivitas terapeutik yang bervariasi sesuai dengan spesies, lokasi geografis, dan proses panen. Kulit jeruk nipis belakangan ini banyak dimanfaatkan sebagai agen antibakteri, karena mengandung senyawa flavonoid yang merupakan golongan terbesar dari senyawa polifenol yang dapat bekerja sebagai antioksidan dan juga sebagai antibakteri dengan mendenaturasi protein sel bakteri dan merusak sel bakteri. Flavonoid juga dapat menghambat aktifitas GTF dari S. mutans, sehingga pemanfaatan ekstrak kulit jeruk nipis diharapkan dapat dikembangkan untuk mencegah pembentukan biofilm. ${ }^{2,8}$

\section{Biofilm}

Hampir seluruh bakteri yang terdapat di alam tumbuh dalam komunitas biofilm. Sel bak teri dalam biofilm memiliki karakteristik yang berbeda dibandingkan dengan sel planktonik. Bio film memberikan banyak keuntungan bagi reproduksi, metabolisme, dan pertahanan bakteri dari bakteri lain maupun inang. ${ }^{9}$

Biofilm adalah komponen yang terdiri dari bakteri yang terbungkus dalam matriks Extr acellular Polymeric Substances (EPS) yang diproduksi sendiri oleh bakteri tersebut. Kumpulan sel-sel mikroba pada biofilm melekat secara irreversibel pada permukaan inert atau hidup, dan d apat bertahan karena kemampuannya untuk menangkap nutrisi, serta tahan terhadap kondisi ling kungan yang tidak baik. Biofilm mikroba terdapat pada setiap bagian di rongga mulut setiap ind ividu. Biofilm terdiri dari berbagai species mikroba, hingga lebih dari 700 spesies berbeda. Bakt eri yang paling dominan dalam rongga mulut manusia, diantaranya S.sanguis, S.mitis, S.mutans, S. salivarius, L. acidophilus, L.salivarius, L. casei, Staphylococcus sp., Eubacterium sp., Neisse ria sp., Actinomyces sp., Peptostreptococcus sp., Micrococcus sp., dll. Streptococcus merupakan jenis yang paling dominan dari berbagai spesies tersebut. Komponen biofilm dewasa sekitar 5-2 5\% sel bakteri dan $75-95 \%$ matriks glikokaliks. ${ }^{1,9,10}$

EPS merupakan komponen utama biofilm. Semua biofilm mengandung EPS, meskipun jenis EPS dalam biofilm bervariasi bergantung dari tingkat pertumbuhan bakteri dan substrat unt 


\section{Review Article}

uk metabolisme bakteri. Hampir semua spesies bakteri dalam biofilm dapat melakukan biosintes is dan mempengaruhi EPS oleh karena itu EPS menjadi media komunikasi antar spesies bakteri. Fungsi lain dari EPS adalah untuk menyediakan perlindungan bagi bakteri karena EPS dapat me mblokir agen berbahaya dari luar biofilm dan meningkatkan konsentrasi nutrisi dan enzim ekstr aseluler untuk biosintesis substrat yang lebih baik. EPS membantu biofilm mempertahankan str uktur biofilm. Meskipun struktur biofilm berubah sesuai dengan spesies bakteri dalam biofilm d an nutrisi yang tersedia di lingkungan, EPS mampu beradaptasidan kompatibel dengan kebutuha $\mathrm{n}$ biofilm. EPS juga mempengaruhi pertukaran ferum dalam biofilm dan mengontrol karakteristi $\mathrm{k}$ hidrofilik atau hidrofobik dari biofilm itu sendiri. ${ }^{9,11}$

Pembentukan mikroorganisme-mikroorganisme mikroba berhubungan dengan infeksi persisten pada jaringan dan benda asing yang resisten terhadap pengobatan dengan agen antimikroba. Hingga $80 \%$ infeksi bakteri pada manusia berhubungan dengan biofilm; dengan infeksi yang paling sering disebabkan oleh Staphylococcus aureus, S. epidermidis, Pseudomonas aeruginosa, dan Escherichia coli. ${ }^{12}$ Sebagai contoh, biofilm plak gigi terdiri dari lusinan spesies dan komposisi komunitas sering menentukanada atau tidak adanya penyakit. Dalam plak gigi, terdapat perkembangan kolonisasi dan adanya spesies yang bermanfaat untuk melawan organisme yang merusak. ${ }^{13}$

Streptococcus dikelompokkan menjadi enam kelompok penting yaitu: kelompok piogen ik, kelompok anginosus, kelompok mitis, kelompok salivarius, kelompok bovis, dan kelompok mutans yang dapat dilihat pada gambar di bawah ini. ${ }^{1}$

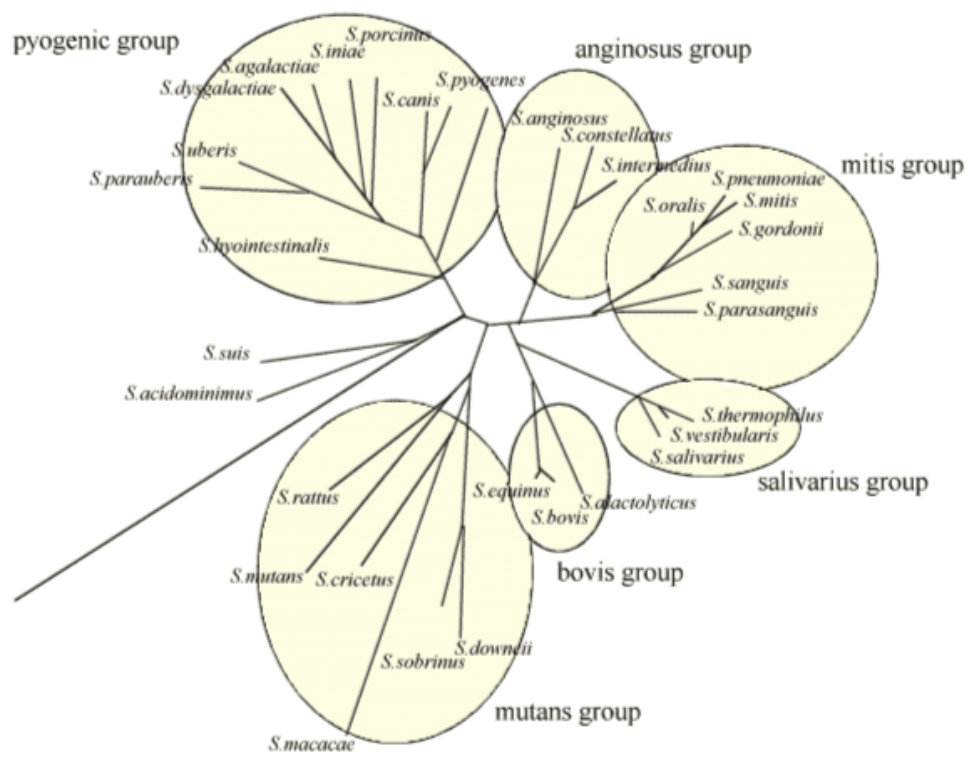

Gambar 1 Phylogenetic tree Genus Streptococcus ${ }^{1}$ 
Strepotococcus mutans adalah bakteri kokus Gram-positif anaerob fakultatif yang munc ul dalam rantai pada pewarnaan Gram. Streptococcus mutans merupakan bakteri yang mendomi nasi rongga mulut namun bersifat tidak patogen. Bakteri ini dapat menjadi patogen dan menyeb abkan penyakit apabila memenuhi beberapa persyaratan dasar. Bakteri harus mampu melekat pa da permukaan jaringan dan bersaing dengan mikrobiota normal yang ada pada permukaan jaring an. Selanjutnya, untuk membentuk biofilm, bakteri planktonik melekat pada permukaan gigi yan g dimediasi oleh kontak elektrostatik atau adhesin permukaan bakteri dan diikuti oleh proliferasi , produksi eksopolisakarida, dan pematangan biofilm. . $^{1,2,5,14}$

Karakteristik dari bakteri Streptococcus mutans antara lain mampu menyintesis polisaka rida ekstraseluler glukan ikatan $\alpha$ (1-3) yang tidak larut dalam air, dapat memproduksi asam lak tat melalui proses homofermentasi, membentuk koloni yang melekat dengan erat pada permukaa n gigi, dan lebih bersifat asidogenik dibanding spesies Streptococcus oral lainnya. Streptococcus mutans menghasilkan polisakarida ekstraseluler dari sukrosa yang menyebabkan karies gigi den gan memanfaatkan enzim glukosil transferase. Zat ekstraseluler ini memiliki ikatan glukosa $\alpha(1-$ 3) yang akan membantu perlekatan bakteri. Polisakarida ekstraseluler juga memiliki fungsi untu kmemberikan energi selama defisiensi karbohidrat. Streptococcus mutans juga menghasilkan $L i$ po Teichoic Acid yang akan melekat pada enamel eksternal sehingga membantu terjadinya prose $\mathrm{s}$ kolonisasi. Koloni ini melekat pada permukaan gigi yang akan memecah gula untuk energi, $\mathrm{m}$ enurunkan $\mathrm{pH}$, membuat lingkungan sekitarnya menjadi asam. Hal ini menyebabkan terjadinya demineralisasi email dan dentin yang pada akhirnya akan berkembang menjadikaries. Streptoco ccus mutans bukan hanya merupakan bakteri utama yang terlibat dalam perkembangan plak, tet api juga untuk permulaan terjadinya karies gigi. ${ }^{1,5,7,11}$ Oleh karena itu, Streptococcus mutans dia nggap sebagai etiologi utama karies gigi melalui pembentukan biofilm yang diawali oleh kehadi ran lapisan tipis saliva yang terdiri dari albumin, glikoprotein, protein kaya prolin, dan senyawa lain yang akan melapisi email gigi disebut pelikel. Adhesin pada permukaan bakteri akan melek at pada pelikel di atas permukaan gigi yang selanjutnya terjadi pertumbuhan biofilm yang melip uti koagregasi dan koadherensi bakteri. Streptococcus mutans pada permukaan gigi akan menyi ntesis polisakarida pada plak gigi dan menyebabkan karies gigi. ${ }^{1,5}$

Sejauh ini, tidak ada teknik yang diketahui efektif untuk mencegah atau menghilangkan pembentukan biofilm yang tidak diinginkan tanpa menimbulkan efek samping yang merugikan. Munculnya resistensi biofilm terhadap perawatan konvensional memunculkan kebutuhan untuk mencari strategi baru. Oleh karena itu diperlukan pencarian alternatif yang lebih aman daripada antibiotik dan bahan kimia lainnya, sehingga antimikroba berbasis tanaman diterima secara luas karena dianggap aman. ${ }^{10}$ 


\section{Jeruk Nipis (Citrus aurantifolia)}

Tanaman jeruk nipis merupakan tanaman semak berduri setinggi 5-6 meter, memiliki batang berduri, tunggal atau ganda dan cabang-cabang yang tidak teratur berwarna coklat hingga abu-abu, daunnya berwarna kuning kehijauan sampai hijau tua. Bunganya berwarna putih, berdiameter 1 inci dan berwarna putih kekuningan, buah berbentuk bulat telur hingga ovoid sekitar 3-6cm dengan warna kuning saat matang. Kulit buahnya sangat tipis dengan segmen kelenjar padat dengan vesikel pulpa kuning-hijau. ${ }^{8,15-17}$ Klasifikasi dari Citrus aurantifolia adalah: Kingdom: Plantae; Division: Magnoliophyta; Class: Magnoliopsida; Order: Sapindales; Family: Rutaceae; Genus: Citrus; Species: C. aurantifolia; Binomial name: Citrus aurantifolia (Christm.) Swingle; Common (local) name: Acid Lime, Key lime (Mexican), Kagzi nimbu (Hindi). ${ }^{8,18}$

Jeruk nipis memiliki aktivitas biologi spektrum luas, diantaranya antibakteri, antivirus, antioksidan, antijamur, aktivitas analgesik, dan antiinflamasi. Buah jeruk nipis kaya akan asam askorbat dan juga senyawa bioaktif lainnya seperti kumarin, karotenoid, limonoid, dan flavonoid. Flavonoid yang berasal dari jeruk telah diketahui memiliki berbagai aktivitas, untuk menangkal radikal bebas, berperan sebagai antioksidan, memodulasi aktivitas enzimatik, dan menghambat proliferasi sel, antivirus, antibakteri, antimikroba, antiinflamasi, anti tumor, dan anti inflamasi. Citrus aurantifolia juga memiliki manfaat dalam mengurangi kecemasan, mengurangi gangguan terkait stres seperti insomnia atau gangguan pencernaan yang berasal dari saraf, juga memiliki potensi antiinflamasi, memiliki sifat antispasmodik yang dialami selama kejang sistem pencernaan (distensi, diare), dan memiliki sifat antikoagulan. ${ }^{6,19-22}$

\section{Kulit Jeruk Nipis (Citrus Aurantifolia)}

Karakter makroskopis dari kulit jeruk nipis dalam keadaan segar atau kering sangat bervariasi. Warna permukaan luar kulit segar adalah hijau cerah hingga kuning dan berubah menjadi kuning kecoklatan saat dikeringkan. Permukaan dalam kulit jeruk nipis segar berwarna putih dan berubah menjadi coklat setelah pengeringan. Kulit jeruk yang segar memiliki bau yang kuat dan dibandingkan kulit yang kering dan memiliki rasa asam dan pahit. Kulit jeruk nipis mengandung banyak kelenjar minyak yang banyak dimanfaatkan sebagai penambah aroma dan rasa. Kulit jeruk kaya akan nutrisi dan mengandung banyak komponen biologi aktif, sehingga dapat digunakan secara efisien sebagai obat atau sebagai suplemen makanan. Berdasarkan penelitian yang telah dilakukan, terbukti bahwa kulit jeruk merupakan sumber flavanoid yang memiliki kemampuan antimikroba. ${ }^{8,21,23}$ 
Ekstrak kulit jeruk nipis memiliki berbagai khasiat, diantaranya melawan kolik, sakit perut, kanker, diuretik, karminatif, lambung, tonik untuk sistem pencernaan, sistem kekebalan tubuh, dan kulit. Selain itu ekstrak kulit jeruk nipis digunakan untuk mengobati dan mencegah kekurangan vitamin, pilek, flu, penyakit kudis, dan membantu memerangi infeksi virus dan bakteri. Beberapa penelitian telah membuktikan aktivitas antibakteri yang kuat dari ekstrak dari kulit jeruk. ${ }^{17,24}$

\section{Peranan Kulit Jeruk Nipis sebagai Antibakteri}

Streptococcus mutans merupakan bakteri utama dalam terjadinya karies gigi melalui akt ifitas enzim glukosiltransferase dalam mengubah sukrosa menjadi fruktosa dan glukan. Enzim i ni dapat dihambat oleh senyawa tertentu seperti polifenol yang didapat pada tanaman herbal sep erti pada ekstrak kulit jeruk nipis. Berdasarkan penelitian yang telah dilakukan oleh Zania, dkk, terbukti bahwa kulit jeruk nipis menghambat aktivitas enzim GTF Streptococcus mutans. Citrus aurantifolia terbukti memiliki aktivitas antibakteri yang signifikan dikaitkan dengan keberadaan beberapa komponen biologi aktif yang dikandungnya seperti flavonoid, limonoid, kumarin, pito sterol, alkaloid, tanin, saponin, steroid, glikosida, karbohidrat, dan fenol. ${ }^{2,15}$

Senyawa fenolik adalah salah satu metabolit tanaman sekunder utama dan dikategorikan ke dalam beberapa kelas, termasuk asam fenolik, flavonoid dan tanin. Flavonoid dicirikan oleh s truktur yang terdiri dari 15 atom karbon (C6-C3-C6). Senyawa fenolik terbukti efektif dalam me nghambat pertumbuhan dan pembentukan biofilm oleh bakteri patogen. Dengan demikian, kond isi yang memengaruhi aktivitas sistem dalam sel bakteri dapat berpengaruh secara langsung terh adap kemampuannya untuk membentuk dan mempertahankan struktur biofilm. ${ }^{25,26}$

Komponen yang paling banyak terdapat dalam kulit jeruk nipis adalah flavonoid,yang te rdiri dari katekin, apigenin, rutin, quercetin, kaempferol, nobiletin, hesperidin, hesperitin, dan ne ohesperidin. Flavonoid dianggap memiliki sifat-sifat yang meningkatkan kesehatan karena kapa sitas antioksidannya yang tinggi, serta menunjukkan aktivitas anti-alergi, anti-inflamasi, antimik roba, dan anti-kanker. ${ }^{15,23}$

Flavonoid disintesis oleh tanaman sebagai respons terhadap infeksi mikroba, oleh karen a itu tidak mengherankan bahwa flavonoid yang ditemukan secara in vitro menjadi zat antimikr oba yang efektif terhadap beragam mikroorganisme. Katekin yang merupakan salah satu senyaw a flavonoid, terbuki memiliki aktivitas antimikroba yang agresif. Senyawa senyawa ini dilapork an berperan sebagai anti bakteri terhadap Streptococcus mutans, Shigella, dan bakteri lainnya. F lavonoid merupakan turunan fenol yang mempunyai kemampuan dalam merusak protein, karen 


\section{Review Article}

a flavonoid memiliki ikatan rangkap antara atom $\mathrm{C}$ nomor 2 dan 3 yang akan bereaksi dengan $\mathrm{g}$ ugus amina pada enzim GTF sehingga mengikat gugus tersebut dan merusak enzim GTF. 2,23

\section{Simpulan}

Ekstrak kulit jeruk nipis (Citrus aurantifolia) efektif digunakan untuk pencegahan plak dan karies gigi. Ekstrak kulit jeruk nipis mengandung senyawa dengan potensi terapeutik dan memiliki efek sebagai zat penghambat pembentukan aktivitas enzim Streptococcus mutans sehingga dapat digunakan untuk menghambat pembentukan biofilm.

\section{Daftar Pustaka}

1. Daboor SM, Syed F, Masood S. A review on Streptococcus mutans with its diseases dental caries, dental plaque and endocarditis. Indian J Microbiol Res 2015;2(2):76-82.

2. Adindaputri ZU, Purwanti N, Wahyudi A. Pengaruh ekstrak kulit jeruk nipis (Citrus aurantifolia swingle) konsentrasi $10 \%$ terhadap aktivitas enzim glukosiltransferase Streptococcus mutans. Maj. Ked. Gigi. 2013;20(2):126-31.

3. Cristina A, Stipp RN, Mattos-graner RDO, Sampaio FC. Influence of sub-lethal and lethal concentrations of chlorhexidine on morphology and glucosyltransferase genes expression in Streptococcus mutans UA159. Adv Microbiol. 2014, 4: 945-54

4. Sapna B Shetty, Ismail MS, Shaji Varghese, Thomas GB, Khandati TP, Baby D, et al. Antimicrobial effects of Citrus sinensis peel extracts against dental caries bacteria: An in vitro study. J Clin Exp Dent. 2016;8(1):70-7.

5. Abachi S, Lee S, Rupasinghe HPV. Molecular mechanisms of inhibition of Streptococcus species by phytochemicals. Infect Genet Evol.2016; 44:376-81.

6. Nwankwo I.U, Osaro-Matthew RC, Ekpe, I.N. Synergistic antibacterial potentials of Citrus aurantifolia (lime) and honey against some bacteria isolated from sputum of patients attending Federal Medical Center Umuahia. Int.J.Curr.Microbiol.App.Sci. 2015;4(4):534-44.

7. Li Y, Burne RA. Regulation of the gtfBC and $\mathrm{ftf}$ genes of Streptococcus mutans in biofilms in response to $\mathrm{pH}$ and carbohydrate. Microbiol. 2018:2841-8.

8. Apraj V, Thakur N, Bhagwat A, Mallya R, Sawant L. Pharmacognostic and phytochemical evaluation of Citrus aurantifolia ( Christm ) swingle peel. Pharmacogn J. 2011;3(26):1-7. doi:10.5530/pj.2011.26.12

9. Huang R, Li M, Gregory RL. Bacterial interactions in dental biofilm. Virulence. 2011. 2(5):435-44.

10. Onsare J, Arora DS. Antibiofilm potential of flavonoids extracted from Moringa oleifera seed coat against Staphylococcus aureus, Pseudomonas aeruginosa and Candida albicans. J Appl Microbiol. 2014;2014:1-13. doi:10.1111/jam.12701

11. Isnarianti R, Wahyudi IA, Puspita RM. Muntingia calabura L leaves extract inhibits glucosyltransferase activity of Streptococcus mutans. J Dent Indonesia.2013;20(3):59-63.

12. Awolola GV, Koorbanally NA, Chenia H, Francis O, Shode FO, Baijnath H. Antibacterial and anti-biofilm activity of flavonoids and triterpenes isolated. Afr J Tradit Complement Altern Med. 2014 11(3):124-31.

13. López D, Vlamakis H, Kolter R. Biofilms. Cold Spring Harb Perspect Biol. 2010;2(7):a000398. doi:10.1101/cshperspect.a000398.

14. Rozen R, Steinberg D, Bachrach G. Streptococcus mutans fructosyltransferase interactions with glucans. FEMS Microbiol Let. 2004:39-43. doi:10.1016/S0378-1097(04)00065-5

15. Pathan R, Gali PR, Pathan P, Gowtham T, Pasupuleti S. In vitro antimicrobial activity of Citrus aurantifolia and its phytochemical screening. Asian Pac J Trop Dis. 2012: 328-31.

16. Loizzo MR, Tundis R, Bonesi M, Menichini F, Luca DD, Menichini F. Evaluation of Citrus aurantifolia peel and leaves extracts for their chemical composition, antioxidant and anti-cholinesterase activities. J Sci Food Agric. 2012;(March). doi:10.1002/jsfa.5708

17. Mohamed SG and Badri AM. Antimicrobial activity of Syzygium aromaticum and Citrus aurantifolia essential oils against some microbes in Khartoum, Sudan. EC Microbiol.2017;6:253-59.

18. Rafiq S, Kaul R, Sofi SA, Bashir N, Nazir F, Ahmad G. Citrus peel as a source of functional ingredient: A review. J Saudi Soc Agric Sci. 2018;17(4):351-8. doi:10.1016/j.jssas.2016.07.006

19. Evbuomwan BO. Analysis and comparative study of essential oil extracted from Nigerian Orange, Lemon and Lime Peels By. Greener J Chem Sci Tech.2014;1(1):6-14. doi: 10.15580/GJCST.2014.1.04141418.

20. Kumar A, Narayani M, Subanthini A, Jayakumar M. Antimicrobial activity and phytochemical analysis of citrus fruit peels -utilization of fruit waste. Int J Eng Science Techn. 2011; 3:5414-21. 


\section{Review Article}

21. Shetty SB, Mahin-syed-ismail P, Varghese S, Thomas-george B, Kandathil- P. Antimicrobial effects of Citrus sinensis peel extracts against dental caries bacteria: An in vitro study. J Clin Exp Dent. 2016;8(1). doi: $10.4317 /$ jced. 52493

22. Al-Snafi AE. Nutritional value and pharmacological importance of citrus species grown in Iraq. IOSR J Pharm. 2016;6(8):76-108.

23. Enejoh OS, Ogunyemi IO, Bala MS,Oruene IS, Suleiman MM, Ambali SF. Ethnomedical importance of Citrus aurantifolia ( Christm ) swingle. Pharma Innov J. 2015; 4(8):1-6.

24. Laenia A, Jessica B, Marciane M, Evandro L, Jose P. de Siqueira-Júnior L. Inhibitory effects offlavonoids on biofilm formation byStaphylococcusaureusthat overexpresses efflux protein genes. Microb Pathog. 2017;107:193-7.

25. Ting Wu, Mengying He, Xixi Zang, Ying Zhou, Tianfu Qiu, Siyi Pan XX. A structure-activity relationship study offlavonoids as inhibitors ofE.coliby membrane interaction effect. Biochim Biophys Acta. 2013;1828:2751-6. 